\title{
Malignant Corneal Neoplasm
}

National Cancer Institute

\section{Source}

National Cancer Institute. Malignant Corneal Neoplasm. NCI Thesaurus. Code C3565.

A malignant growth of cells within the cornea of the eye. 